\title{
PROFESJONALIZM PIELĘGNIAREK
}

\section{JAKO ELEMENT OCENY SATYSFAKCJI RODZICÓW/OPIEKUNÓW DZIECI Z OPIEKI PIELĘGNIARSKIEJ}

\author{
NURSES' PROFESSIONALISM AS A COMPONENT OF EVALUATION \\ OF PARENTS/CAREGIVERS SATISFACTION WITH NURSING CARE
}

Uniwersytet Medyczny w Lublinie / Medical University of Lublin, Lublin, Poland

Wydział Nauk o Zdrowiu, Katedra i Zakład Zarządzania w Pielęgniarstwie / Health Sciences Department,

Chair and Department of Management in Nursing

\begin{abstract}
STRESZCZENiE
Wstęp: Profesjonalizm to realizowanie usług z wykorzystaniem wiedzy i umiejętności oraz odpowiedzialność za podejmowane działania. Stanowi ważny element poddawany ocenie w pomiarze jakości opieki. Opinie pacjentów i ich rodzin (mierzone poziomem satysfakcji) dotyczące profesjonalizmu pracowników medycznych pozwalają na doskonalenie jakości świadczeń zdrowotnych. Materiał i metody: Badaniem objęto 120 rodziców/opiekunów dzieci hospitalizowanych na oddziale pediatrii. Metodą badawczą był sondaż diagnostyczny, a narzędziem badawczym - „Standaryzowany kwestionariusz oceny poziomu zadowolenia rodziców/opiekunów z opieki pielęgniarskiej” autorstwa Latoura i wsp., który przez autorki niniejszej publikacji został dostosowany do warunków krajowego szpitalnictwa pediatrycznego i poddany walidacji. Do analizy materiału prezentowanego w niniejszej pracy wybrano jedną z części narzędzia dotyczącą profesjonalizmu opieki pielęgniarskiej. W analizie statystycznej zastosowano testy: Manna-Whitneya oraz Kruskala-Wallisa. Jako poziom istotności statystycznej przyjęto $\mathrm{p} \leq 0,05$. Dobór respondentów był losowy. Rodzice/opiekunowie otrzymywali narzędzie dzień przed planowanym wypisem. Wyniki: Ogólny wskaźnik oceny profesjonalizmu opieki pielęgniarskiej przez rodziców/opiekunów był wysoki i wyniósł 4,3. Wyższą satysfakcję rodzice/opiekunowie dzieci wyrazili w przypadku szacunku okazywanego pacjentom przez pielęgniarki, a niższa dotyczyła przedstawiania się pielęgniarek pacjentom $(4,7$ vs 3,2$)$. Wysoki poziom zadowolenia rodziców/opiekunów odnosi się do możliwości ich współpracy z zespołem terapeutycznym $(4,6)$, organizacji pracy pielęgniarek $(4,6)$ oraz jakości opieki pielęgniarskiej $(4,6)$. Wnioski: Rodzice/opiekunowie wyrazili zadowolenie z profesjonalizmu opieki pielęgniarskiej. Zmiennymi istotnie różnicującymi opinie rodziców/opiekunów na temat wybranych kryteriów szczegółowych związanych z profesjonalizmem opieki pielęgniarskiej były: wykształcenie badanych oraz częstość i przyczyna hospitalizacji dzieci. Czas hospitalizacji i wiek dzieci oraz miejsce zamieszkania rodziców/opiekunów nie korelowały z poziomem satysfakcji rodziców z profesjonalizmu opieki pielęgniarskiej. Med. Pr. 2015;66(4):549-556
\end{abstract}

Słowa kluczowe: satysfakcja pacjenta, dziecko hospitalizowane, opiekunowie, rodzice, jakość opieki zdrowotnej, pediatria

\begin{abstract}
Background: Professionalism in nursing means the provision of medical and nursing services based on the best knowledge and skills, as well as on great responsibility for the undertaken actions. The opinions of patients and their families concerning professionalism, reflected in the level of satisfaction, contribute to the improvement of the quality of services offered. Material and Methods: The study covered 120 parents/caregivers of children hospitalized in a pediatric ward. Diagnostic survey method was applied in the research. The standardized questionnaire for evaluation of the level of parents/caregivers satisfaction with nursing care (Latour et al.) adjusted to the conditions of Polish pediatric hospital services and subjected to validation was adopted as a research tool. Statistical analysis was performed using the Mann-Whitney U test and Kruskal-Wallis test. A value of $\mathrm{p} \leq 0.05$ was considered to indicate statistical significance. The respondents were selected at random. The parents/caregivers received the questionnaire the day before the child's discharge. Results: The parents/caregivers generally evaluated the professionalism of nursing care in positive terms (4.3). They expressed higher satisfaction with respect showed by nurses for patients (4.7), while lower satisfaction with nurses introducing themselves (3.2). A high level of satisfaction was obtained with respect to the parents/caregivers' opinions pertaining to cooperation within a therapeutic team (4.6), organization of nurses' work (4.6), and quality of nursing care (4.6). Conclusions: Parents/caregivers expressed their satisfaction with the professionalism of nursing care. Education of respondents, frequency and reasons for hospitalization among children proved to be the variables that significantly differed the opinions of parents/caregivers concerning the selected criteria for professionalism of nursing care. No correlation was found between the duration of hospitalization, children's age, place of parents/caregivers residence, and the level of satisfaction with professionalism of nursing care. Med Pr 2015;66(4):549-556
\end{abstract}

Key words: patient satisfaction, hospitalized child, caregivers, parents, quality of health care, paediatrics

Autorka do korespondencji / Corresponding author: Ewa Smoleń, Uniwersytet Medyczny w Lublinie, Wydział Nauk o Zdrowiu, Katedra i Zakład Zarządzania w Pielęgniarstwie, ul. Staszica 4-6, 20-081 Lublin, e-mail: ewasmolen@op.pl

Nadesłano: 21 listopada 2014, zatwierdzono: 20 lipca 2015 


\section{WSTĘP}

System ochrony zdrowia w Polsce podlega transformacji od ponad 2 dekad [1]. Zmieniają się potrzeby odbiorców usług, z czego wynikają coraz wyższe wymagania wobec świadczeniodawców. Zarządzający zakładami opieki zdrowotnej dążą do zapewnienia większej sprawności i efektywności pracy w instytucjach medycznych [2]. Ukierunkowanie działań pracowników zakładów opieki zdrowotnej na podniesienie jakości oferowanych świadczeń to istotne wyzwanie dla zatrudnionych w systemie ochrony zdrowia.

Jakość świadczeń zdrowotnych w znacznym stopniu jest uwarunkowana interakcją między usługodawcą a klientem [3]. W systemie ochrony zdrowia zapewnia się świadczenia medyczne w ramach kompleksowej opieki medycznej. Powinny one stanowić źródło satysfakcji dla świadczeniobiorcy oraz świadczącego opiekę podmiotu $[2,3]$. Istotą analizy jakości usług medycznych jest badanie związku między jakością opieki a satysfakcją klienta. Opinie świadczeniobiorców są wartościowym źródłem informacji na temat ich potrzeb i oczekiwań, co umożliwia analizowanie sytuacji i wprowadzanie zmian [3].

Profesjonalizm to $\mathrm{w}$ procesie oferowania świadczeń połączenie wiedzy, umiejętności i odpowiedzialności za wykonywanie zadań. Pielęgniarstwo cechują podejmowanie działań na rzecz ludzkiego zdrowia oraz autonomia zawodowa związana $\mathrm{z}$ nadzorem i oceną własnej działalności zawodowej, a także dążenie do zapewnienia dobrej jakości opieki [4].

Satysfakcja pacjentów jest definiowana jako różnica między tym, co pacjent otrzymuje, a jego oczekiwania$\mathrm{mi}$ [3]. W wielu polskich badaniach autorzy w pomiarze satysfakcji pacjentów stosują kwestionariusze własnego autorstwa. Dotyczy to także narzędzi stosowanych w praktyce przez zarządzających zakładami opieki zdrowotnej. Przegląd piśmiennictwa i analiza wykorzystywanych w praktyce kwestionariuszy do pomiaru satysfakcji pacjentów i ich rodzin wykazały, że w polskim systemie zdrowotnym brakuje kompleksowego, wystandaryzowanego narzędzia do pomiaru satysfakcji [5]. Narzędziem, które spełnia te wymagania, jest „Standaryzowany kwestionariusz oceny poziomu zadowolenia rodziców/opiekunów z opieki pielęgniarskiej” („Questionnaire measuring parent satisfaction in the pediatric care") autorstwa Latoura i wsp. [6].

Celem niniejszych badań była ocena poziomu satysfakcji z profesjonalizmu opieki pielęgniarskiej dokonana przez rodziców/opiekunów dzieci hospitalizowanych na oddziale pediatrii.

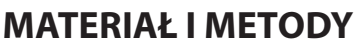

Badania prowadzono metodą sondażu diagnostycznego od sierpnia 2012 r. do marca 2013 r. Uczestniczyło w nich anonimowo 120 rodziców dzieci hospitalizowanych na Oddziale Pediatrii Szpitala Specjalistycznego Samodzielnego Zespołu Opieki Zdrowotnej w Sanoku. Dobór respondentów był losowy. Rodzice/opiekunowie otrzymywali narzędzie dzień przed planowanym wypisem dziecka ze szpitala. Badania rozpoczęto po otrzymaniu zgody (nr KE-0254/163/2012) na nie Komisji Bioetycznej Uniwersytetu Medycznego w Lublinie oraz kadry zarządzającej szpitalem i oddziałem.

Jako narzędzie badawcze zastosowano „Standaryzowany kwestionariusz oceny poziomu zadowolenia rodziców/opiekunów z opieki pielęgniarskiej” autorstwa Latoura i wsp. [6]. Autorki niniejszej publikacji dostosowały go do warunków krajowego szpitalnictwa pediatrycznego i poddały walidacji [7]. Kwestionariusz składa się z 5 części (kryteriów głównych) i przypisanych im łącznie 44 kryteriów szczegółowych:

kryterium I - informacje (8 kryteriów szczegółowych),

kryterium II - opieka i leczenie (9 kryteriów szczegółowych),

kryterium III - dostępność (2 kryteria szczegółowe),

kryterium IV - udział rodziców (6 kryteriów szczegółowych),

- kryterium V - profesjonalne podejście (19 kryteriów szczegółowych).

Poszczególne kryteria szczegółowe rodzice/opiekunowie dzieci hospitalizowanych oceniali według skali Likerta (1 - najniższy stopień zadowolenia, 5 - najwyższy). Wyniki badań przedstawiono w postaci średniej arytmetycznej (M). Dla potrzeb niniejszego artykułu satysfakcję oceniano $\mathrm{z}$ wykorzystaniem części ww. kwestionariusza, tj. kryterium V (profesjonalne podejście) i przypisanych mu 19 kryteriów szczegółowych [7]:

1. Widoczna była współpraca w zespole pielęgniarsko-lekarskim.

2. Rodzice/opiekunowie wiedzieli, która pielęgniarka opiekuje się ich dzieckiem.

3. Pielęgniarka przedstawiła się $\mathrm{z}$ imienia i nazwiska.

4. Praca pielęgniarki na dyżurze była dobrze zorganizowana.

5. Praca zespołu pielęgniarskiego zapewniła dziecku poczucie bezpieczeństwa.

6. Najbliższe otoczenie dziecka było czyste. 
7. Informacje pisemne dotyczące zasad funkcjonowania oddziału były w miejscu dostępnym dla rodziców/opiekunów.

8. Godziny odwiedzin były elastyczne.

9. Zapewnione było zakwaterowanie dla rodziców/ /opiekunów w pobliżu oddziału.

10. Pielęgniarka zapewniła opiekę wysokiej jakości niezależnie od rasy, wyznania, płci i wykształcenia pacjenta.

11. Pielęgniarka chroniła prywatność dziecka.

12. Pielęgniarka chroniła prywatność rodziców/opiekunów.

13. Pielęgniarka odnosiła się z szacunkiem do rodziców/opiekunów.

14. Pielęgniarka powstrzymywała się od zbędnych dyskusji przy łóżku dziecka.

15. Pielęgniarka okazywała empatię dziecku.

16. Pielęgniarka okazywała empatię rodzicom/opiekunom.

17. Pielęgniarka miło witała rodziców/opiekunów przy przyjęciu/odwiedzinach.

18. Zmiana atmosfery w pracy nie wpływała na poziom świadczonych usług pielęgniarki wobec dziecka.

19. Zdrowie dziecka było priorytetem dla pielęgniarki.

Poszczególne kryteria profesjonalizmu zestawiono ze zmiennymi: wiekiem dziecka, czasem trwania, liczbą i przyczyną hospitalizacji pacjentów, a także liczbą dzieci $\mathrm{w}$ rodzinie. Interpretowano również zależność kryteriów szczegółowych profesjonalnego podejścia od płci, wieku i wykształcenia rodziców dzieci przebywających na oddziale szpitalnym. W analizie statystycznej zastosowano nieparametryczne testy - Manna-Whitneya $(\mathrm{t})$ oraz Kruskala-Wallisa $(\mathrm{H})$. Jako poziom istotności statystycznej przyjęto $\mathrm{p} \leq 0,05$.

\section{WYNIKI}

Wiek hospitalizowanych dzieci nie różnicował istotnie szczegółowych kryteriów profesjonalizmu opieki pielę- gniarskiej w opinii rodziców/opiekunów ( $p>0,05)$. Zależność istotną statystycznie wykazano w zakresie satysfakcji z bazy noclegowej dla rodziców/opiekunów, z której bardziej zadowoleni byli rodzice/opiekunowie noworodków, a mniej rodzice/opiekunowie dzieci w wieku $1-6$ lat $(4,8$ pkt vs 4 pkt $)(\mathrm{p} \leq 0,05)$. W opinii rodziców/opiekunów dzieci pielęgniarka częściej zapewniała poczucie bezpieczeństwa dzieciom $\mathrm{w}$ wieku 13-18 lat (5 pkt) niż niemowlętom (4,4 pkt) ( $\mathrm{p}>0,05)$.

$\mathrm{Na}$ podobnym poziomie rodzice/opiekunowie, bez względu na liczbę potomstwa, ocenili uzyskanie informacji, która $\mathrm{z}$ pielęgniarek opiekuje się ich dzieckiem (4,1 pkt), ochronę prywatności dziecka przez pielęgniarkę (4,6 pkt), szacunek pielęgniarki do opiekunów (4,7 pkt) i powstrzymywanie się od zbędnych dyskusji pielęgniarki przy łóżku dziecka (4,5 pkt). Wyższy poziom satysfakcji w zakresie profesjonalizmu deklarowali rodzice/opiekunowie dwojga i więcej dzieci.

Rodzice/opiekunowie mający 2 dzieci istotnie lepiej niż mający 1 dziecko ocenili współpracę między pracownikami oddziału (4,8 pkt vs 4,5 pkt, $\mathrm{p} \leq 0,05)$, zapewnienie czystości w otoczeniu dziecka (4,7 pkt vs 4,3, $\mathrm{p} \leq 0,05)$, dostępność pisemnych informacji o zasadach funkcjonowania oddziału (4 pkt vs 4,4 pkt, $\mathrm{p} \leq 0,05$ ) oraz zapewnienie bazy noclegowej $(4,4$ pkt vs 3,8 pkt, $\mathrm{p} \leq 0,05)$. Również zdecydowanie częściej w opinii rodziców/opiekunów mających minimum 2 dzieci $(4,6$ pkt) niż w opinii mających 1 dziecko zmiana atmosfery w pracy na oddziale nie wpływała istotnie na poziom świadczeń medycznych (4,6 pkt vs 4,3 pkt, $\mathrm{p} \leq 0,05)$.

Nieznacznie wyżej profesjonalizm opieki pielęgniarskiej ocenili rodzice/opiekunowie dzieci hospitalizowanych na oddziale częściej niż raz. Wyniki dotyczące zadowolenia $\mathrm{z}$ opieki w zestawieniu z liczbą hospitalizacji przedstawiono w tabeli 1 .

Poziom empatii okazywanej przez pielęgniarkę rodzicom/opiekunom został oceniony przez nich na tym samym poziomie bez względu na liczbę hospita-

Tabela 1. Satysfakcja rodziców/opiekunów z opieki pielęgniarskiej vs liczba pobytów dziecka na oddziale pediatrii

Table 1. Parents/caregivers' satisfaction with nursing care vs. number of hospitalizations of the child in a pediatric ward

\begin{tabular}{|c|c|c|c|c|}
\hline \multirow{2}{*}{$\begin{array}{c}\text { Hospitalizacja } \\
\text { Hospitalisation } \\
{[\mathrm{n}]}\end{array}$} & \multirow{2}{*}{$\begin{array}{c}\text { Respondenci } \\
\text { Respondents } \\
\text { [n] }\end{array}$} & \multicolumn{3}{|c|}{$\begin{array}{l}\text { Profesjonalizm opieki pielęgniarskiej }{ }^{*} \\
\text { Professionalism in nursing care }\end{array}$} \\
\hline & & $\mathrm{M} \pm \mathrm{SD}$ & $\begin{array}{l}\min .-\operatorname{maks} \\
\min .-\max \end{array}$ & $\begin{array}{l}\text { test Manna-Whitneya } \\
\text { Mann-Whitney U test }\end{array}$ \\
\hline 1 & 100 & $4,3 \pm 0,6$ & $2,3-5,0$ & 0,01 \\
\hline$\geq 2$ & 20 & $4,6 \pm 0,5$ & $3,1-5,0$ & 0,01 \\
\hline
\end{tabular}

* Według 5-punktowej skali Likerta / Based on a 5-point Likert's scale.

M - średnia / mean, SD - odchylenie standardowe / standard deviation, min. - wartość minimalna / minimal value, maks. - wartość maksymalna / max - maximal value. 
lizacji dziecka (3,9 pkt). Rodzice/opiekunowie dzieci przebywających w szpitalu po raz kolejny wskazali na wyższy poziom satysfakcji z uzyskania informacji, która z pielęgniarek opiekuje się ich dzieckiem, niż rodzice/opiekunowie dzieci hospitalizowanych po raz pierwszy (4,5 pkt vs 4 pkt, $\mathrm{p} \leq 0,05)$. Zapewnienie wysokiej jakości opieki przez pielęgniarki bez względu na rasę, religię, płeć i wykształcenie pacjentów rodzice/opiekunowie ocenili na tym samym wysokim poziomie podczas pierwszego i kolejnego pobytu w szpitalu (4,7 pkt).

Zdaniem rodziców/opiekunów dzieci hospitalizowanych więcej niż raz pielęgniarka lepiej chroniła ich prywatność niż w opinii rodziców/opiekunów przebywających $\mathrm{z}$ dziećmi w szpitalu po raz pierwszy $(4,9 \mathrm{pkt}$ vs 4,5 pkt, $\mathrm{p} \leq 0,05)$. W opinii rodziców/opiekunów $\mathrm{w}$ niniejszym badaniu pielęgniarka przedstawiała się im z imienia i nazwiska częściej wtedy, gdy deklarowali kolejną hospitalizację, a nie tylko jeden pobyt dziecka w szpitalu (4,1 pkt vs 3 pkt, p $\leq 0,05)$, oraz zdecydowanie częściej powstrzymywała się od zbędnych dyskusji przy łóżku dziecka (4,7 pkt vs 4,5 pkt, p $\leq 0,05)$.

Czystość otoczenia dziecka najwyżej ocenili rodzice/opiekunowie dzieci hospitalizowanych powyżej $28 \mathrm{dni}$, natomiast najniżej - hospitalizowanych 8-14 dni $(4,9$ pkt vs 4,1 pkt, p $\leq 0,05)$. Zapewnienie wysokiej jakości opieki bez względu na rasę, religię, płeć i wykształcenie pacjentów najwyżej ocenili rodzice/opiekunowie dzieci przebywających na oddziale do $7 \mathrm{dni}$ i powyżej $15 \mathrm{dni}$, a najniżej - dzieci przebywających 8-14 dni $(4,8$ pkt vs 4,4 pkt, p $\leq 0,05)$.

Profesjonalizm opieki pielęgniarskiej (kryterium V w kwestionariuszu) lepiej ocenili rodzice/opiekunowie dzieci przyjętych planowo niż przeniesionych $\mathrm{z}$ innego oddziału (4,4 pkt vs 3,7 pkt, p $\leq 0,05)$. Rodzice/opiekunowie dzieci przyjętych nagle wyższą satysfakcję wyra- żali w odniesieniu do warunków noclegowych (4,4 pkt vs 3,3 pkt, $\mathrm{p} \leq 0,05)$ oraz zapewnienia przez pielęgniarkę wysokiej jakości opieki bez względu na rasę, religię i płeć pacjentów $(4,7$ pkt vs 4,5 pkt, $\mathrm{p} \leq 0,05)$.

Profesjonalizm opieki pielęgniarskiej lepiej oceniły kobiety niż mężczyźni (4,3 pkt vs 4,1 pkt, p $\leq 0,05)$. Miejsce zamieszkania rodziców/opiekunów nie różnicowało istotnie statystycznie poszczególnych kryteriów głównych i szczegółowych profesjonalnego podejścia pielęgniarek $(\mathrm{p}>0,5)$.

Zależności istotnych statystycznie nie wykazano też między poziomem wykształcenia rodziców/opiekunów a satysfakcją z profesjonalizmu opieki pielęgniarskiej (tab. 2). Z kolei profesjonalizm opieki pielęgniarskiej w niniejszym badaniu najwyżej ocenili rodzice/ lopiekunowie z wykształceniem podstawowym (tab. 3).

\section{OMÓWIENIE}

Działania kadry pielęgniarskiej mają na celu zapewnienie wysokiej jakości opieki odpowiadającej obowiązującym standardom. W pracy pielęgniarki duże znaczenie mają kompetencje, które są warunkiem sprawowania profesjonalnej opieki. Profesjonalizm jest ważną cechą działań podejmowanych przez pielęgniarki, która może podlegać ocenie nie tylko przełożonych, ale także pacjentów i ich rodzin. W pediatrii oceny profesjonalizmu opieki pielęgniarskiej dokonują przede wszystkim rodzice/opiekunowie dzieci.

Od kilkunastu lat w Polsce wielu autorów prowadzi badania dotyczące pomiaru satysfakcji odbiorców świadczeń zdrowotnych w ramach opieki pielęgniarskiej [8-12]. Niestety badania te prowadzone są przy pomocy niestandaryzowanych narzędzi, co znacznie zmniejsza ich wartość badawczą. W niniejszych badaniach profesjonalizm opieki pielęgniarskiej w opinii

Tabela 2. Ocena profesjonalizmu opieki pielęgniarskiej vs wykształcenie rodziców/opiekunów

Table 2. Professionalism in nursing care vs. level of education and satisfaction of parents/caregivers

\begin{tabular}{|c|c|c|c|c|}
\hline \multirow{2}{*}{$\begin{array}{l}\text { Wykształcenie } \\
\text { Education }\end{array}$} & \multirow{2}{*}{$\begin{array}{c}\text { Respondenci } \\
\text { Respondents } \\
\text { [n] }\end{array}$} & \multicolumn{3}{|c|}{$\begin{array}{l}\text { Profesjonalizm opieki pielęgniarskiej* } \\
\text { Professionalism in nursing care }\end{array}$} \\
\hline & & $\mathrm{M} \pm \mathrm{SD}$ & $\begin{array}{l}\min .- \text { maks. } \\
\min .-\max \end{array}$ & $\begin{array}{l}\text { test Kruskala-Wallisa } \\
\text { Kruskal-Wallis test }\end{array}$ \\
\hline Podstawowe / Primary & 13 & $4,5 \pm 0,4$ & $3,8-5$ & 0,419 \\
\hline Zawodowe / Vocational & 16 & $4,2 \pm 0,6$ & $2,9-5$ & 0,419 \\
\hline Średnie / Secondary & 50 & $4,3 \pm 0,7$ & $2,3-5$ & 0,419 \\
\hline Wyższe / Higher & 40 & $4,3 \pm 0,6$ & $3,1-5$ & 0,419 \\
\hline
\end{tabular}

Objaśnienia jak w tabeli 1 / Abbreviations as in Table 1. 


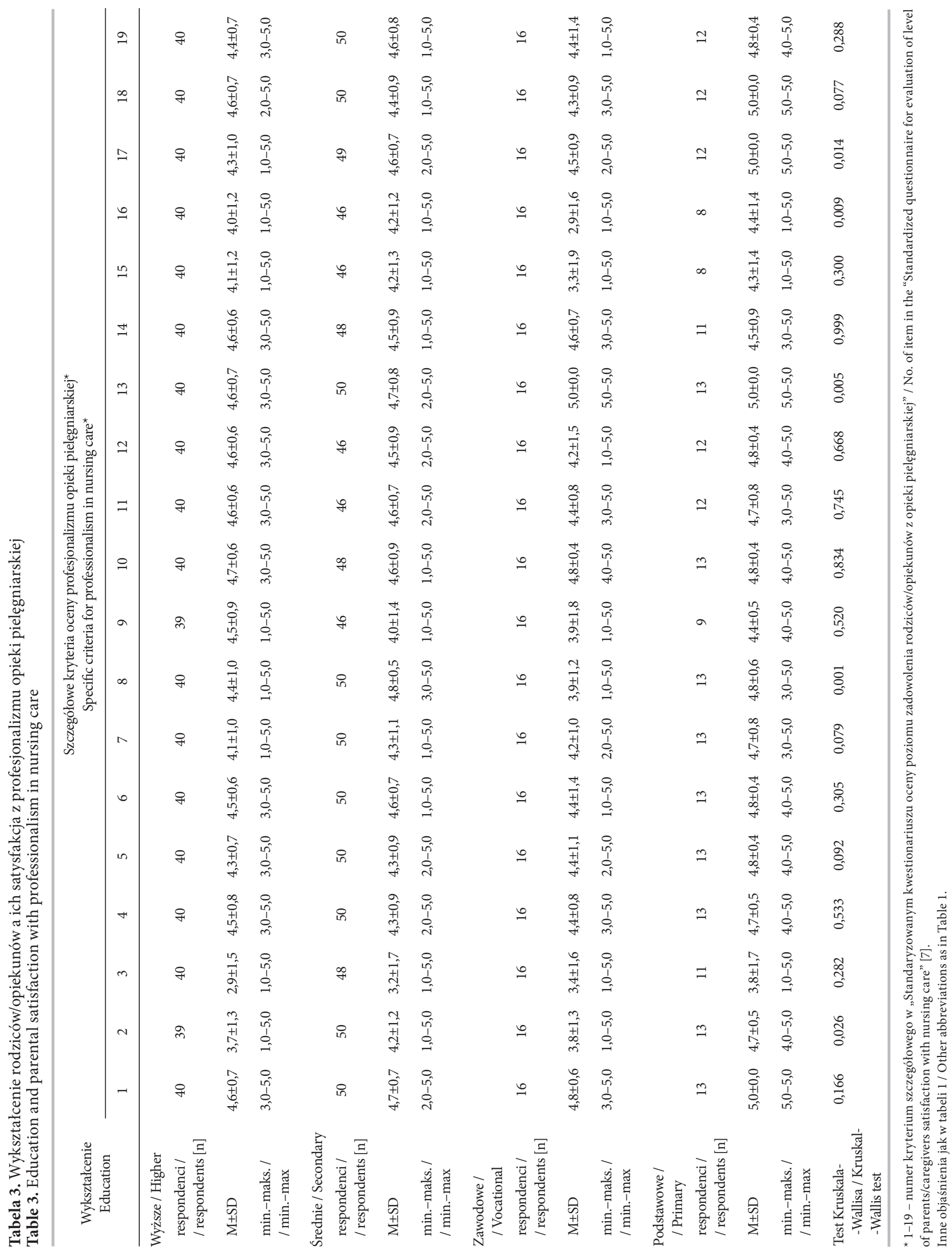


rodziców/opiekunów dzieci hospitalizowanych na pediatrycznym oddziale szpitalnym oceniono $\mathrm{z}$ zastosowaniem standaryzowanego narzędzia badawczego. Wynika $\mathrm{z}$ tego innowacyjny charakter badań. W polskim piśmiennictwie nie ma wyników analogicznych badań przeprowadzonych wśród rodziców/opiekunów dzieci hospitalizowanych na oddziale pediatrii.

W niniejszych badaniach kryterium główne dotyczące profesjonalizmu najwyżej ocenili rodzice/opiekunowie dzieci w wieku 13-18 lat, kobiety i rodzice/opiekunowie dzieci będących w początkowym etapie hospitalizacji oraz przebywających w szpitalu powyżej 2 tygodni. Zdaniem innych autorów $[8,10]$ profesjonalizm pracy pielęgniarki jest ważnym źródłem zadowolenia rodziców/opiekunów z opieki. Należy jednak zauważyć, że cytowani autorzy nie zdefiniowali pojęcia profesjonalizmu opieki pielęgniarskiej, a w jego ocenie posłużyli się tylko 1 kryterium z kwestionariusza własnego autorstwa.

Zdaniem Latoura i wsp. [6] oraz autorek niniejszego artykułu przyjmowanie jednego znaczenia terminu 'profesjonalizm' bez próby jego zdefiniowania może prowadzić do niezrozumienia istoty zagadnienia przez osoby biorące udział $\mathrm{w}$ badaniu. Na profesjonalizm składają się różne zadania pielęgniarek - m.in. współpraca w zespole, okazywanie szacunku i empatii, ochrona prywatności itp. (tab. 3) - stąd wyniki badań innych autorów [8-11] należy traktować z dystansem.

W niniejszych badaniach wysoką satysfakcję z profesjonalnego podejścia pielęgniarek do pacjentów na oddziale pediatrii deklarowali rodzice/opiekunowie dzieci przyjętych planowo. Podobnie wysoki wskaźnik zadowolenia rodziców/opiekunów z profesjonalnego podejścia pielęgniarek uzyskali także Bednarek i wsp. [9]. Zgodnie z wynikami ich badań zaplanowana hospitalizacja zarówno w opinii 45\% pielęgniarek, jak i 11,3\% rodziców sprzyja łatwiejszej adaptacji dziecka do warunków szpitalnych. W badaniach Bilickiej [10] wszyscy rodzice dzieci przyjętych na leczenie zabiegowe wysoko ocenili opiekę pielęgniarską, natomiast w przypadku hospitalizacji, której celem była diagnostyka, taką ocenę wystawiło tylko $62 \%$ rodziców. W badaniach innych autorów, którzy w ocenie zadowolenia z opieki posługiwali się autorskimi narzędziami, przyczyna hospitalizacji nie wpływała na satysfakcję rodziców/opiekunów dzieci z usług pielęgniarskich [11].

Wyników niniejszego badania i innych polskich autorów nie można ze sobą porównać ze względu na stosowanie $\mathrm{w}$ ocenie zadowolenia pacjentów $\mathrm{z}$ opieki niestandaryzowanych narzędzi badawczych. Narzędzie użyte w niniejszej pracy dostosowano do polskich warunków.
W opinii większości rodziców/opiekunów poczucie bezpieczeństwa dziecka jest większe, kiedy podczas leczenia szpitalnego przebywają z nim rodzice/opiekunowie [12]. W niniejszych badaniach $\mathrm{z}$ warunków pobytu bardziej usatysfakcjonowani byli rodzice/opiekunowie dzieci przyjętych nagle i noworodków, a także mający minimum 2 dzieci. W badaniach Łukasik i wsp. [12] blisko $1 / 4$ rodziców/opiekunów $(23,8 \%)$ uznała odpowiednie warunki noclegowe za ważny dla nich element wpływający na zadowolenie $\mathrm{z}$ hospitalizacji. $\mathrm{Z}$ dotychczas prowadzonych badań - nawet z zastosowaniem autorskich narzędzi badawczych - wynika, że 65,5\% rodziców/opiekunów, przebywających z dziećmi podczas hospitalizacji, brak odpowiednich warunków lokalowo-materialnych na oddziale szpitalnym uznaje za wadę, która wpływa na ocenę opieki podczas hospitalizacji dziecka [12]. W opinii 50\% pielęgniarek i zaledwie $15 \%$ rodziców/opiekunów dzieci warunki lokalowe pomagają w adaptacji dziecka do warunków szpitalnych [9]. Wskazuje to, jak bardzo w opinii rodziców/opiekunów warunki pobytu wpływają na proces leczenia i opieki na dzieckiem.

$\mathrm{W}$ niniejszych badaniach na oddziale pediatrii zapewnienie bezpieczeństwa dziecku przez pielęgniarkę wyżej ocenili rodzice/opiekunowie dzieci w wieku 13-18 lat, a w najmniejszym - rodzice/opiekunowie niemowląt. W badaniach Sochockiej i wsp. [11] większość rodziców/opiekunów $(79,5 \%)$ twierdziła, że to pielęgniarka zapewnia bezpieczeństwo dziecku, stanowiące priorytet $\mathrm{w}$ opiece nad pacjentem hospitalizowanym na oddziale pediatrii. W innych badaniach, w których oceniano tylko wybrane elementy profesjonalizmu opieki pielęgniarskiej, 37,8\% rodziców/opiekunów dzieci hospitalizowanych wyraziło zadowolenie $\mathrm{z}$ zapewnienia przez pielęgniarki bezpieczeństwa fizycznego i psychicznego rodzicom/opiekunom. Zdecydowanie więcej $(98,1 \%)$ rodziców/opiekunów wskazało na satysfakcjonujące ich zapewnienie przez pielęgniarki bezpieczeństwa dziecku [13]. Zdaniem 68,8\% rodziców/opiekunów i 65\% pielęgniarek proces adaptacji do warunków szpitalnych jest trudniejszy u młodszych dzieci [9].

Z empatii okazywanej rodzicom/opiekunom zdecydowanie bardziej w niniejszych badaniach usatysfakcjonowane były kobiety oraz badani mający wykształcenie podstawowe lub średnie. Liczba hospitalizacji nie wpływała na zadowolenie rodziców/opiekunów z empatii pielęgniarek $\mathrm{w}$ stosunku do rodziców. Jak wynika $\mathrm{z}$ badań przeprowadzonych przez innych autorów z zastosowaniem niestandaryzowanych kwestionariuszy do oceny profesjonalizmu opieki pielęgniar- 
skiej [13], rodzice/opiekunowie coraz częściej w odpowiedzi na empatię pielęgniarek obdarzają je zaufaniem i szacunkiem. W Polsce nie prowadzono analogicznych badań, które pozwoliłyby na porównanie z nimi wyników uzyskanych w niniejszym badaniu.

Oprócz sposobu komunikowania się z pacjentem ważny element zwiększenia efektywności opieki nad dzieckiem hospitalizowanym stanowią w opinii rodziców/opiekunów warunki lokalowe w zakładzie opieki zdrowotnej [8]. W niniejszych badaniach zapewnienie czystości w otoczeniu dziecka zostało ocenione wysoko, a w najwyższym stopniu usatysfakcjonowani byli rodzice/opiekunowie z wykształceniem podstawowym, mający przynajmniej 2 dzieci, oraz rodzice/opiekunowie dzieci w wieku powyżej 7 lat. Dbałość o higienę otoczenia dziecka najniżej ocenili rodzice/opiekunowie dzieci hospitalizowanych przez 8-14 dni. W badaniach Bilickiej i wsp. estetykę sal chorych - podobnie jak w niniejszych badaniach - wysoko ocenili rodzice/opiekunowie dzieci hospitalizowanych na oddziale chirurgii dziecięcej w Bydgoszczy (86\%) [10].

Wyższy poziom satysfakcji z informowania, która pielęgniarka opiekuje się dzieckiem, przedstawiania się przez pielęgniarkę z imienia i nazwiska, ochrony prywatności rodziców oraz powstrzymywania się od zbędnych komentarzy w obecności dziecka deklarowali w niniejszych badaniach rodzice/opiekunowie dzieci hospitalizowanych kolejny raz oraz z wykształceniem podstawowym. Uzyskane wyniki korespondują z opinią rodziców/opiekunów, którzy w badaniach przeprowadzonych przez innych autorów [8,9] z zastosowaniem autorskich narzędzi badawczych wskazali, że znajomość przez rodziców/opiekunów danych personalnych pielęgniarki uspokaja, budzi zaufanie i daje poczucie bezpieczeństwa. W badaniach Bednarek i wsp. [13] 90\% rodziców znało imię i nazwisko pielęgniarki opiekującej się ich dzieckiem. Jednocześnie brak tej wiedzy jest powodem niezadowolenia rodziców z opieki [11].

Życzliwość kadry pielęgniarskiej to cecha najczęściej oczekiwana przez rodziców/opiekunów $(25,8 \%)$ dzieci hospitalizowanych na oddziałach dziecięcych [14]. $\mathrm{W}$ niniejszych badaniach miłe powitanie przez pielęgniarkę przy przyjęciu rodziców/opiekunów zdecydowanie lepiej ocenili badani z wykształceniem podstawowym niż z wyższym. Podobne wyniki uzyskali Bednarek i wsp. [13].

W niniejszych badaniach rodzice/opiekunowie wysoko ocenili odnoszenie się pielęgniarek $\mathrm{z}$ szacunkiem do rodziców/opiekunów. W badaniach Bednarek i wsp. [13] tylko 48,3\% rodziców dzieci hospitalizo- wanych wskazało na traktowanie ich przez pielęgniarki z szacunkiem. Inni autorzy raportują $80,6 \%$ rodziców/opiekunów deklarujących szacunek pielęgniarek do ich dziecka i dostrzeganie potrzeb pacjenta hospitalizowanego na oddziale dziecięcym [8]. Podobne wyniki uzyskali Gawlik i wsp. [14], w których badaniu 90\% rodziców wskazało traktowanie ich dziecka podczas hospitalizacji z szacunkiem, a 95\% - poszanowanie przez pielęgniarki jego godności. W badaniach prowadzonych na oddziale pediatrii w Bielsku-Białej 98,8\% rodziców spotkało się z życzliwym przyjęciem przez pielęgniarki [15].

Podsumowując, należy podkreślić, że przedstawienie w niniejszym artykule badań na temat kompleksowej oceny satysfakcji z opieki pediatrycznej w zakresie profesjonalizacji opieki pielęgniarskiej jest istotną nowością. Takie badania po raz pierwszy w naszym kraju zostały przeprowadzone standaryzowanym i walidowanym narzędziem badawczym. Zaprezentowane podejście metodologiczne, w odróżnieniu od prac innych autorów, zapewnia kompleksową analizę problematyki jakości opieki pielęgniarskiej.

\section{WNIOSKI}

Poziom zadowolenia rodziców/opiekunów z wybranych cech profesjonalizmu opieki pielęgniarskiej był w niniejszych badaniach wysoki. Zmiennymi, które istotnie różnicowały ich opinie dotyczące wybranych kryteriów szczegółowych związanych z profesjonalizmem opieki pielęgniarskiej, były wykształcenie respondentów oraz częstość i przyczyna hospitalizacji dzieci.

Czas hospitalizacji i wiek dzieci oraz miejsce zamieszkania rodziców/opiekunów nie korelowały z poziomem satysfakcji respondentów z profesjonalizmu opieki pielęgniarskiej.

\section{PIŚMIENNICTWO}

1. Nęcki Z., Kęsy M. [red.]: Postawy personelu medycznego wobec zarządzania szpitalem. Wydawnictwo Uniwersytetu Jagiellońskiego, Kraków 2013

2. Krawczyński M. [red.]: Propedeutyka pediatrii. Wydawnictwo Lekarskie PZWL, Warszawa 2003

3. Karkowski T.: Zarządzanie relacjami pielęgniarka-pacjent w usługach medycznych. W: Pietrzak B., Karkowski T. [red.]. Zarządzanie personelem pielęgniarskim $\mathrm{w}$ podmiotach leczniczych. Zagadnienia wybrane. Wydawnictwo ABC a Wolters Kluwer Business, Warszawa 2013 , ss. $185-214$ 
4. Poznańska S.: Pielęgniarstwo. W: Ślusarska B., Zarzycka D., Zahradniczek K. [red.]. Podstawy pielęgniarstwa. Tom I. Wydawnictwo PZWL, Warszawa 2011, ss. 21-34

5. Smoleń E., Ksykiewicz-Dorota A.: Przegląd narzędzi stosowanych w pomiarze satysfakcji rodziców/opiekunów z opieki w pediatrii. Przegl. Pediatr. 2013;43(1):30-34

6. Latour J.M., Hazelzet J.A., Duivenvoorden H.J., van Goudoever J.B.: Construction of a parent satisfaction instrument: Perceptions of pediatric intensive care nurses and physicians. J. Crit. Care 2009;24:255-266, http://dx.doi. org/10.1016/j.jcrc.2008.06.002

7. Smoleń E., Ksykiewicz-Dorota A.: Validation of the Polish version of the questionnaire of parents' satisfaction with nursing care at the paediatric department. Med. Biol. Sci. 2015;29(1):41-46, http://dx.doi.org/10.12775/ MBS.2015.006

8. Bednarek A., Mianowana W., Jachorek M.: Oczekiwania rodziców hospitalizowanych noworodków w zakresie realizowanej opieki. Część I. Probl. Pielęg. 2011;19(1):27-33

9. Bednarek A., Machul R.: Uwarunkowania reakcji dzieci na hospitalizację w oddziale chirurgicznym - opinia rodziców i pielęgniarek. PiZ 2013;14(10, Cz. 2):151-167
10. Bilicka D., Korbińska M., Popow A., Szewczyk M.T.: Oczekiwania rodziców względem opieki pielęgniarskiej nad dzieckiem w warunkach szpitalnych. Pielęg. Chir. Angiol. 2009;1:20-25

11. Sochocka L., Wojtyłko A.: Poczucie satysfakcji podopiecznych Oddziału Chirurgii Dziecięcej WCM w Opolu a model opieki funkcjonujący w Oddziale. Pielęg. Zdrow. Publiczne 2011;1(1):19-25

12. Łukasik R., Waksmundzka W., Gawlik K.: Aspekty pobytu rodziców wraz z dzieckiem w szpitalu. Probl. Pielęg. 2010;18(2):169-175

13. Bednarek A., Mianowana W., Jachorek M.: Zakres funkcji profilaktycznej i promocji zdrowia w pracy pielęgniarki pediatrycznej a oczekiwania rodziców hospitalizowanych noworodków. Część II. Probl. Pielęg. 2011;19(3):296-302

14. Gawlik K., Waksmańska W., Łukasik R.: Opieka pielęgniarska nad dzieckiem hospitalizowanym w opinii rodziców. Pielęg. XXI w. 2012;1(38):11-14

15. Waksmańska W., Łukasik R., Gawlik K., Makowska-Songin J.: Oczekiwania rodzin pacjentów a postawy personelu medycznego - analiza na przykładzie Szpitala Pediatrycznego w Bielsku-Białej. Probl. Pielęg. 2012;20(1):70-75

Zezwala się na korzystanie z artykułu „Profesjonalizm pielęgniarek jako element oceny satysfakcji rodziców/opiekunów dzieci z opieki pielęgniarskiej” w modelu open access na warunkach licencji Creative Commons Uznanie autorstwa - Użycie niekomercyjne 3.0 (znanej również jako CC-BY-NC), dostępnej pod adresem http://creativecommons.org/licenses/by-nc/3.0/pl/ lub innej wersji językowej tej licencji, lub którejkolwiek późniejszej wersji tej licencji, opublikowanej przez organizację Creative Commons / The use of the article "Nurses' professionalism as a component of evaluation of parents/caregivers satisfaction with nursing care" is available in Open Access model and permitted under license conditions of Creative Commons Attribution-NonCommercial 3.0 (also known as CC-BY-NC), available at http://creativecommons.org/licenses/by-nc/3.0/pl/deed.en or another language version of this license or any later version of this license published by Creative Commons. 